\title{
Faaliyet Kaldıraç Derecesinin Satış Gelirleri Üzerindeki Etkisi: Havayolu Şirketlerinde Bir Uygulama
}

\section{The Effect of Operating Leverage Degree on Revenues: An Application in Airlines}

\author{
Dr. Öğr. Üyesi Faruk DAYI
}

\begin{abstract}
$\ddot{O} z$
Sivil havacılık sektörü, hızla büyüyen dinamik bir sektördür. Yolcu sayısındaki artış, yeni uçuş noktaları ve düşük fiyatlı uçak biletleri sektörün büyümesinde etkili olmaktadır. Ancak sivil havacılık sektörü yüksek bütçeli yatırımlar gerektirmektedir. Personel ve yakıt maliyetlerinin yüksek oluşu sektördeki rekabet düzeyini düşürmektedir. Havayolu şirketleri uçuş başına sabit maliyetleri karşıladıktan sonraki satılan her bilet, şirketin marjinal kârını artırmaktadır. Bu nedenle yüksek tutarlarda sabit maliyet ile faaliyet gösteren havayolu şirketlerinin faaliyet kaldıracı ile satış gelirleri arasındaki ilişkinin incelenmesinin literatüre katkı sağlaması beklenmektedir. Çalışmanın uygulamasında satış geliri, faaliyet kaldıraç derecesi, finansal kiralama giderleri, aktif kârlılık oranı ve özsermaye kârllık oranı değişkenlerinden oluşan bir model geliştirilmiştir. Dünyanın her kıtasından en az bir şirket olmak üzere 20 havayolu şirketinin verileri kullanılmıştır. Veri seti 2010-2016 dönemini kapsamaktadır. Panel veri yöntemiyle analiz yapılmıştır. Analiz sonuçlarına göre faaliyet kaldıraç derecesi ile satış gelirleri arasında pozitif yönde bir korelasyon tespit edilmiştir. Uçaktaki yolcu sayısı arttıkça, kaldıraç etkisiyle daha fazla satı̧ geliri elde edilmektedir. Doluluk oranının artması şirketlerin performansını da olumlu yönde etkilemiştir. Finansal kiralama giderleri ile satış gelirleri arasında pozitif yönlü bir ilişki vardır. Satış gelirleri ile aktif kârlılık oranı arasında da pozitif yönlü bir ilişki tespit edilmiştir. Analizde Özsermaye kârlılık oranı anlamsız çıkmıştır. Uygulama kapsamındaki havayolu şirketlerinin negatif Özkaynaklara sahip olmasının oranın anlamsız çıkmasını etkileyebileceği düşünülmektedir.
\end{abstract}

Anahtar Kelimeler: Sivil havacılık, faaliyet kaldıracı, panel veri, finansal kiralama

Makale Türü: Araştırma

\begin{abstract}
Civil Aviation is a rapidly growing dynamic sector. The increase in the number of passengers, new destination and the sale of low-priced airline tickets are effective in the growth of the sector. However, civil aviation sector requires high budget investments. Staff and fuel costs are the biggest problems in the sector for competing. Each ticket sold after the airline costs fixed costs increases the marginal profit of the company. In this study, it is aimed that examining the relationship between the operating leverage and the revenues of the airlines operating at fixed costs with high amount. A model consisting of revenues, operating leverage, financial leasing expenses, asset profitability ratio and return on equity ratio has been developed. In the application, data of 20 airlines, at least one company from every continent of the World, were used. The data set covers the period 2010-2016. Panel data analysis was performed. There is a positive correlation between operating leverage and revenues. The higher the number of passengers on board, the higher the revenues due to leverage. The increase in the occupancy rate also positively affected the performance of the companies. There is a positive relationship between finance leasing expenses and revenues. There is a positive relationship between revenues and asset profitability ratio.
\end{abstract}

Keywords: Civil aviation, operating leverage, panel data, leasing

Paper Type: Research

${ }^{1}$ Kastamonu Üniversitesi, İktisadi ve İdari Bilimler Fakültesi, fdayi@kastamonu.edu.tr.

Atıf için (to cite): Dayı, F. (2019). Faaliyet Kaldıraç Derecesinin Satış Gelirleri Üzerindeki Etkisi: Havayolu Şirketlerinde Bir Uygulama. Afyon Kocatepe Üniversitesi Sosyal Bilimler Dergisi, 21(3), 923-941. 


\section{Giriş}

Havayolu şirketlerinin sayısının artmasıyla birlikte sivil havacılık sektöründe yoğun bir rekabet yaşanmaktadır. Destinasyonların artmasıyla, yolcular istedikleri yere kolayca gidebilmektedir. Havayolu şirketleri ekonomideki büyümeye paralel olarak büyüyen önemli bir hizmet sektörüdür. Günümüz teknolojisiyle üretilen uçakların yolcu kapasitesinin eskilerinden fazla olması, daha az yakıt ile daha fazla mesafe uçabilmeleri ve yolcuların seyahat alışkanlıklarının değişmesi sivil havacılık sektörünün büyümesinde etkili olmuştur. Ayrıca 2010 yılında ham petrolün varil fiyatı 80 \$'dan, 2012 yılında 125\$'a kadar yükselmiş ancak sonraki yıllar düşüş trendine girerek 2016 yılında 30 \$-35\$ bandına kadar düşmüştür. Önemli bir maliyet unsuru olan yakıt maliyetlerinin düşmesi, havayolu şirketlerinin toplam maliyetlerini azaltmış, daha rekabetçi bilet fiyatı sunabilmelerine imkân tanımıştır. Yakıt maliyetlerinin düşmesi şirketlerin kârını artırırken personel maliyetlerinde herhangi bir düşüşün olmaması aksine yükselmesi ve sektördeki görülen yüksek rekabet şirketlerin büyümelerini olumsuz yönde etkilemiştir.

Havayolu şirketlerinde yakıt ve personel giderleri şirketler için önemli bir maliyet unsurudur. Yakıt maliyetlerinin düşürülmesi için birim kilometre başına daha az yakıt tüketen yeni nesil teknoloji ile üretilmiş uçaklar satın alınmaktadır. Personel giderlerini kısmak pek mümkün olmasa da, kabin personelinin sayısı azaltılarak uçuş başına personel maliyeti düşürülebilmektedir. Havayolu şirketlerinin önemli bir maliyet unsuru da uçakta yapılan ikramlardır. Türk Hava Yolları başta olmak üzere bazı havayolu şirketleri uçakta uçan şef hizmeti sunmaktadır. Böylece kaliteli ve lezzetli yemekler sunarak, yüksek tutarlı ikram maliyetlerine katlanmaktadır. Bazı havayolu şirketleri ise ikram maliyetlerini düşürmektedir. Bazı şirketlerde ise ücret karşıllı̆ında ikram yapılmaktadır.

Sivil havacılık sektöründe karşılaşılan en yüksek giderlerden biri de uçak fiyatlarının yüksek olmasıdır. Sivil havacılık sektörü yoğun sermaye gerektiren bir sektör olduğundan, uçak satın almak için yüksek tutarlarda sermayeye ihtiyaç duyulmaktadır. Havayolu şirketleri bazı durumlarda özkaynakları yeterli gelmediğinde, yabancı kaynaklar ile duran varlıklarını finanse etmektedir. Yabancı kaynakların tutarı ve vadesi arttıkça borçlanmanın maliyeti de artmakta, şirketlerin toplam giderleri yükselmektedir. Dolayısıyla faaliyet kaldıracından yararlanmak isteyen şirketlerin borçlanmaları, şirketlerin finansal durumlarını olumsuz yönde etkileyebilmektedir (Novy-Marx, 2011: 201). Bu nedenlerden dolayı şirketler yüksek tutarlı uçakları satın almaktansa kiralama yöntemini tercih etmektedir. Sivil havacılık sektöründe kiralama, faaliyet kiralaması ve finansal kiralama olmak üzere iki farklı şekilde görülmektedir. Faaliyet kiralamasında, uçak kabin ekibi ile birlikte belirli bir süre için bir havayolu şirketinden kiralanmaktadır. Finansal kiralamada ise havayolu şirketi başlangıçta bir bedel ödemeden finansal kiralama şirketinden uçak kiralamakta, sözleşme süresince kira öder gibi taksit ödeyerek, sözleşme sonunda sembolik bir bedel ile uçağı satın alarak mülkiyetine geçirmektedir.

Havayolu şirketleri satış gelirlerini artırabilmeleri için koltuk doluluk oranını maksimum düzeye çıkarmaları, toplam maliyetlerini düşürmeleri, uçuş sürelerini artırmaları yâda bilet fiyatlarını yükseltmeleri ile mümkündür. Bir uçağın gün içinde yapacağı uçuş süresi sabit olduğundan, uçak sayısı veya doluluk oranındaki artış ile satış gelirlerini artırmak mümkün olabilmektedir. Uçak satın alamayan havayolu şirketleri ise varlıklarını verimli kullanarak filosundaki uçaklarıyla maksimum sayıda yolcu taşıyarak satış gelirlerini artırabilirler. Çünkü uçaklar yüksek tutarlı varlıklar olduğundan onları satın almak finansmanı açısından pek kolay değildir. Ayrıca uçakların satın alınması için verilen siparişler yıllar sonra teslim edilmektedir. $\mathrm{Bu}$ nedenlerden dolayı havayolu şirketlerinin kapasitelerini kısa süre içinde artırmaları pek mümkün görünmemektedir.

Havayolu şirketlerinde sabit giderler yüksek olup değişken giderlerin tutarları daha azdır. Örneğin Boeing Şirketinin en ucuz yolcu uçağı olan Boeing 777-700 modelinin 2017 yılı 
fiyat1 80 milyon USD civarındadır. Bir havayolu şirketinin 10 tane Boeing 777-700 uçağı satın alması yaklaşık 8 milyar USD bütçe gerektirmektedir. Dolayısıyla sivil havacılık sektöründe faaliyet gösteren şirketlerin sabit varlık yatırımları oldukça yüksektir. Bu nedenle havayolu şirketlerinin sabit giderlerinin yüksek oluşu, faaliyet kaldıracından yararlanmasına imkân tanımaktadır. Çünkü bir uçuşta katlanılan sabit maliyetler, uçaktaki yolcu sayısıyla doğrudan ilişkili olmadığından, uçağın boş veya dolu uçması değişken maliyetleri doğrudan etkilemektedir. Satılan biletlerin küçük bir kısmı uçuş için gerekli sabit maliyetleri karşılandıktan sonra, satılan her bilet için sadece değişken maliyet olacağından, ilave her yolcunun marjinal geliri marjinal maliyetinden daha yüksektir. Böylece uçaktaki doluluk oranı arttıkça faaliyet kaldıracının etkisiyle şirketlerin satış gelirleri, brüt satış kârı ve faaliyet kârı yükselmektedir. Faaliyet kaldıracının etkisiyle, belirli sayıda yolcudan sonra uçan her yolcunun marjinal gelirinin marjinal maliyetinden (değişken gider) çıkarılmasıyla kalan tutar şirketlerin kârını doğrudan artırmaktadır. Havayolu şirketleri için geçerli olan bu durum diğer taşımacılık sektörleri içinde geçerlidir. Faaliyet kaldıracının havayolu şirketlerinin satış gelirleri üzerinde önemli bir etkiye sahip olması çalışmanın önemini ortaya koymaktadır. Bu nedenle sivil havacılık sektöründe faaliyet gösteren havayolu şirketlerinin faaliyet kaldıracının, satış gelirleri (Hasılat) üzerindeki etkisinin incelenmesinin literatüre önemli katkı sağlaması beklenmektedir. Bu çalışmada 20 havayolu şirketinin 2010-2016 dönemi verileri kullanılarak satış gelirleri ile faaliyet kaldıracı arasındaki ilişki incelenmiştir.

\section{Sivil Havacılık Sektörünün Finansal Durumu}

Günümüz küresel ekonomi sisteminde sivil havacılık sektörü de hızlı bir ivmeyle büyümektedir. IATA (International Air Transport Association-Uluslararası Hava Taşımacılığ Birliği) 2017 yılında yayınladığı raporda, havayolu taşımacılığının uluslararası ticaretteki değerinin 2016 yılında 5,5 trilyon dolar olduğu ve aynı y1l turistlerin uçuşlarından toplam 650 milyar dolar gelir elde edildiği belirtilmiştir (IATA, 2017). Dünya sivil havacılık sektöründe 2016 yılında yolcu doluluk oran1 \%80,4; kargo doluluk oran1 ise \%46,9 düzeyinde gerçekleşmiştir (IATA, 2017). Havayolu taşımacılığının kıtalar arasındaki dağılımı incelendiğinde \%33,6'lık oran ile en büyük pay Asya-Pasifik kıtasında, \%26,1'lik pay ile Avrupa kıtası ikinci sırada ve \%22,8'lik pay ile Kuzey Amerika kıtası ise üçüncü sırada yer almaktadır (IATA, 2017). 2016 yllında RPK (Revenue Passengers Kilometers- Kilometre Başına Yolcu Geliri), bir önceki yıla göre \%7,4 oranında yükselmiştir (IATA, 2017). RPK sivil havacılık sektöründe sıkça kullanılan bir terimdir. Havayolu şirketleri kilometre başına taşıdıkları ücretli yolculardan elde ettikleri geliri RPK terimi ile göstermektedir. RPK sıralaması, havayolu şirketlerin verimliliklerinin değerlendirilmesinde kullanılan göstergelerden sadece biri olup IATA tarafindan şirketlerin sıralanmasında sıcça kullanılmaktadır. RPK değerlerine göre dünyanın en büyük 10 havayolu şirketinin listesi Tablo 1'de verilmiştir.

Tablo 1. 2016 yılı RPK sonuçlarına göre en büyük 10 havayolu şirketi

\begin{tabular}{lc}
\hline Havayolu Şirketleri & RPK \\
\hline American Airlines & 320.044 \\
Delta Airlines & 308.088 \\
United Airlines & 299.080 \\
Emirates & 270.797 \\
China Southern Airlines & 205.720 \\
Southwest Airlines & 200.848 \\
Lufthansa & 149.702 \\
British Airways & 144.028 \\
Ryanair & 142.740 \\
China Eastern Airlines & 138.042 \\
\hline
\end{tabular}

Kaynak: (IATA, 2017) 
RPK sıralamasına göre 320.044 RPK ile Amerikan Airlines birinci sırada, 308.088 RPK ile Delta Airlines ikinci sırada ve 299.080 RPK ile United Airlines üçüncü sırada olup bu şirketlerin merkezi Amerika kıtasındadır. 138.042 RPK ile China Eastern Airlines en son sırada yer almaktadır. Ucuz uçak bileti ile dünyada tanınan Ryanair şirketi ise 142.740 RPK ile dokuzuncu sırada yer almaktadır.

Dünyada sivil havacılık sektöründe çok sayıda havayolu şirketi faaliyet göstermektedir. Çalışmanın uygulamasında tüm şirketlerin verilerine ulaşmak mümkün olmadığından, her kıtadan en az bir şirket olmak üzere dünya genelinde verisine ulaşılabilen 20 havayolu şirketinin 2010-2016 dönemi satış gelirleri Tablo 2'de verilmiştir.

Tablo 2. Havayolu şirketlerinin satış gelirleri (milyon USD)

\begin{tabular}{lccccccc}
\hline Havayolu Firmaları & $\mathbf{2 0 1 0}$ & $\mathbf{2 0 1 1}$ & $\mathbf{2 0 1 2}$ & $\mathbf{2 0 1 3}$ & $\mathbf{2 0 1 4}$ & $\mathbf{2 0 1 5}$ & $\mathbf{2 0 1 6}$ \\
\hline Air Asia & 584 & 658 & 794 & 844 & 873 & 970 & 934 \\
Air Berlin Group & 5.146 & 5.469 & 5.688 & 5.711 & 5.054 & 4.453 & 3.990 \\
Air China & 11.934 & 14.199 & 15.724 & 16.217 & 17.061 & 16.775 & 16.405 \\
Air France- KLM & 31.573 & 24.679 & 33.839 & 35.151 & 30.268 & 28.029 & 26.191 \\
Air New Zeland & 4.046 & 4.341 & 4.483 & 4.615 & 4.652 & 4.925 & 5.231 \\
ANA Holdings & 15.103 & 17.527 & 16.390 & 14.128 & 13.396 & 14.233 & 15.318 \\
American Airlines & 22.170 & 23.979 & 24.855 & 26.743 & 42.650 & 40.990 & 40.180 \\
Cathay Pacific & 11.504 & 12.655 & 12.820 & 12.431 & 13.154 & 13.202 & 11.946 \\
China Eastern Airlines & 10.918 & 12.220 & 13.774 & 15.026 & 15.125 & 15.284 & 15.025 \\
China Southern Airlines & 11.216 & 13.235 & 15.761 & 16.278 & 17.496 & 17.195 & 16.551 \\
Delta Airlines & 31.755 & 35.115 & 36.670 & 37.773 & 40.362 & 40.704 & 39.639 \\
Easyjet & 4.720 & 5.380 & 6.251 & 6.876 & 7.343 & 7.109 & 6.051 \\
Emirates & 11.832 & 14.593 & 16.961 & 19.323 & 21.916 & 23.512 & 22.925 \\
Lufthansa & 36.667 & 38.522 & 40.958 & 41.359 & 36.463 & 34.976 & 33.376 \\
Qantas Airways & 13.528 & 14.654 & 15.128 & 17.818 & 18.734 & 21.630 & 22.422 \\
Ryanair & 4.007 & 4.695 & 5.706 & 6.727 & 6.119 & 6.169 & 6.889 \\
Singapore Airlines & 9.077 & 11.521 & 11.815 & 12.165 & 12.111 & 11.332 & 11.295 \\
Southwest Airlines & 12.104 & 15.658 & 17.088 & 17.699 & 18.605 & 19.820 & 20.425 \\
Turkish Airlines & 4.990 & 4.099 & 5.925 & 8.813 & 10.382 & 9.853 & 8.373 \\
United Airlines & 23.325 & 37.003 & 37.152 & 38.279 & 38.901 & 37.864 & 36.556 \\
\hline Toplam & $\mathbf{2 7 6 . 9 1 6}$ & $\mathbf{3 0 9 . 8 3 3}$ & $\mathbf{3 3 8 . 1 1 1}$ & $\mathbf{3 5 3 . 9 2 7}$ & $\mathbf{3 6 9 . 7 6 6}$ & $\mathbf{3 6 8 . 5 1 0}$ & $\mathbf{3 5 8 . 6 3 1}$ \\
\hline
\end{tabular}

Tabloda yer alan şirketlerin verilerinin karşılaştırılabilmesi için ortak bir para birimi gerekmektedir. Air New Zealand, ANA Holdings, American Airlines, Cathay Pasific, Delta Airlines, Emirates, Qantas Airways, Southwest Airlines ve United Airlines havayolu şirketlerinin mali tabloları Amerikan doları para birimiyle sunulduğundan verilerde herhangi bir değişiklik yapılmamıştır. Diğer şirketlerin mali tablo verileri, mali tabloların düzenlendiği tarihteki çapraz kur yöntemiyle Amerikan dolarına çevrilmiştir. Amerikan dolarına dönüştürülürken uygulanan çapraz kurlar Tablo 3'de verilmiştir.

Tablo 3. Satış gelirlerinin hesaplanmasında kullanılan çapraz kurlar

\begin{tabular}{lccccccc}
\hline Çapraz Kurlar & $\mathbf{2 0 1 0}$ & $\mathbf{2 0 1 1}$ & $\mathbf{2 0 1 2}$ & $\mathbf{2 0 1 3}$ & $\mathbf{2 0 1 4}$ & $\mathbf{2 0 1 5}$ & $\mathbf{2 0 1 6}$ \\
\hline USD/TL & 1,54 & 1,89 & 1,78 & 2,13 & 2,33 & 2,92 & 3,52 \\
Euro/USD & 1,34 & 1,29 & 1,32 & 1,38 & 1,22 & 1,09 & 1,05 \\
USD/Yuan & 6,82 & 6,83 & 6,23 & 6,05 & 6,21 & 6,49 & 6,95 \\
USD/ Hong Kong & 0,13 & 0,13 & 0,13 & 0,13 & 0,13 & 0,13 & 0,13 \\
Dolar1 & & & & & & & \\
Paund/USD & 1,55 & 1,54 & 1,62 & 1,65 & 1,56 & 1,48 & 1,23 \\
USD/Singapur Dolar1 & 1,28 & 1,30 & 1,22 & 1,26 & 1,33 & 1,42 & 1,45
\end{tabular}

Kaynak: (TCMB, 2018) ve (Exchange, 2018). 
Air New Zealand ve Qantas Airways şirketlerinin yıllık mali tabloları 30 Haziran; Ana Holdings, Emirates ve Singapore Airlines şirketlerinin 31 Mart ve Easyjet şirketinin ise 30 Eylül itibariyle mali tabloları düzenlenmektedir. Bu nedenle mali tabloları Amerikan doları para biriminden düzenlenmeyen şirketlerin ilgili tarihlerde mali tablo verileri Amerikan dolarına çevrilerek düzenlenmiştir. Aynı şekilde Türk Hava Yollarının mali tablo verileri, TCMB veri tabanından ilgili hesap yılının son işlem günündeki Amerikan doları alış kuru üzerinden çevrilerek hesaplanmıştır.

Tablo 2 incelendiğinde havayolu şirketlerinin satış gelirlerinin 2014 yılına kadar düzenli olarak arttığı, 2015 ve 2016 yılında ise düştüğü gözlemlenmiştir. Havayolu şirketlerinin 2010 yılı ile 2016 yılları satış gelirlerinin toplamları karşılaştırıldığında, 7 yıllık dönemde üç havayolu şirketi haricinde hepsinin satış gelirlerinin 2016 yılı ortalaması alındığında \%29,50 oranında satışların arttığı tespit edilmiştir. Aynı dönemde Air Berlin, Air France-KLM ve Lufthansa havayolu şirketlerinin satış gelirleri ise düşmüştür. 2010-2016 döneminde satış gelirlerinde \%91 ile en çok artış Emirates havayolu şirketinde görülmüştür. Havayolu şirketlerinin satış gelirlerinin artmasında en önemli faktörlerden biri yolcu doluluk oranıdır. Şirketlerin yolcu sayısının artması koltuk arzı sabitken yolcu doluluk oranını artırmaktadır. Çalışmanın örnekleminde yer alan havayolu şirketlerinin 2010-2016 dönemi yolcu sayıları Tablo 4'de verilmiştir.

Tablo 4. Havayolu șirketlerinin yolcu say1ları (bin kiși)

\begin{tabular}{lccccccc}
\hline Havayolu Firmaları & $\mathbf{2 0 1 0}$ & $\mathbf{2 0 1 1}$ & $\mathbf{2 0 1 2}$ & $\mathbf{2 0 1 3}$ & $\mathbf{2 0 1 4}$ & $\mathbf{2 0 1 5}$ & $\mathbf{2 0 1 6}$ \\
\hline Air Asia & 16.054 & 17.986 & 19.678 & 21.853 & 22.138 & 24.254 & 26.410 \\
Air Berlin Group & 34.889 & 35.300 & 33.346 & 31.536 & 31.716 & 30.249 & 28.920 \\
Air China & 60.006 & 69.692 & 72.416 & 77.676 & 83.009 & 89.815 & 96.605 \\
Air France - KLM & 71.320 & 59.340 & 77.448 & 86.224 & 87.358 & 89.836 & 93.442 \\
Air New Zeland & 8.018 & 8.530 & 8.500 & 8.694 & 8.920 & 9.246 & 9.275 \\
ANA Holdings & 44.560 & 45.742 & 44.903 & 47.465 & 49.004 & 50.411 & 50.831 \\
American Airlines & 86.086 & 86.042 & 86.330 & 197.340 & 201.250 & 198.710 & 199.640 \\
Cathay Pacific & 26.796 & 27.581 & 28.961 & 29.920 & 31.570 & 34.065 & 34.323 \\
China Eastern Airlines & 64.930 & 68.725 & 73.077 & 79.093 & 83.811 & 93.779 & 101.741 \\
China Southern Airlines & 76.455 & 80.675 & 86.483 & 91.790 & 100.910 & 109.420 & 114.610 \\
Delta Airlines & 162.615 & 163.838 & 164.572 & 171.360 & 179.380 & 183.740 & 186.390 \\
Easyjet & 48.800 & 54.500 & 58.400 & 60.800 & 64.800 & 68.600 & 73.100 \\
Emirates & 27.454 & 31.422 & 33.981 & 39.391 & 44.537 & 48.100 & 51.900 \\
Lufthansa & 92.693 & 100.605 & 103.051 & 104.953 & 105.988 & 107.679 & 109.670 \\
Qantas Airways & 41.428 & 44.456 & 46.707 & 48.276 & 48.776 & 49.181 & 51.246 \\
Ryanair & 66.500 & 72.100 & 75.800 & 79.300 & 81.700 & 90.600 & 106.400 \\
Singapore Airlines & 16.480 & 16.647 & 17.155 & 18.210 & 18.628 & 18.737 & 19.029 \\
Southwest Airlines & 88.191 & 103.974 & 109.347 & 108.075 & 110.496 & 118.171 & 124.719 \\
Turkish Airlines & 29.119 & 32.648 & 39.045 & 48.268 & 54.675 & 61.248 & 62.759 \\
United Airlines & 87.327 & 96.517 & 93.595 & 92.329 & 91.475 & 96.327 & 101.007 \\
\hline Topam & $\mathbf{1 1 4 9 . 7 2 1}$ & $\mathbf{1 . 2 1 6 . 3 1 3}$ & $\mathbf{1 . 2 7 2 . 7 9 5}$ & $\mathbf{1 . 4 4 2 . 5 5 3}$ & $\mathbf{1 . 5 0 0 . 1 4 1}$ & $\mathbf{1 . 5 7 2 . 1 6 8}$ & $\mathbf{1 . 6 4 2 . 0 1 7}$
\end{tabular}

\begin{tabular}{llllllll} 
Toplam & 1.149 .721 & 1.216 .313 & 1.272 .795 & 1.442 .553 & 1.500 .141 & 1.572 .168 & 1.642 .017 \\
\hline
\end{tabular}

Amerikan Airlines şirketinin 2010, 2011 ve 2012 yılları verileri diğerlerinden farklılık göstermektedir. Çünkü Amerikan Airlines şirketi ile US Airways şirketi 2013 yılında birleşerek Amerikan Airlines adı altında faaliyetlerini devam ettirmektedir. Tablo 4'de incelendiğinde, 2010 y1lında 1.149 .721 bin ve 2016 yilında ise 1.642 .017 yolcunun seyahat ettiği görülmektedir. Böylece örneklemdeki havayolu şirketlerinin 2010-2016 döneminde yolcu sayısı ortalama \%42,81 oranında artış göstermiştir. Amerikan Airlines şirketinin 2010-2016 döneminde yolcu sayısında \%131 oranında artış görülmüştür. Bu oran örneklemdeki şirketler arasında en yüksek değer olmasına rağmen, 2013 yılında iki şirketin birleşmesinden dolayı yolcu sayısında artış olmuştur. Amerikan Airlines şirketinin birleşmeden önceki 3 yıllık dönemde (2010-2012) ise 
sadece 244 yolcunun daha uçtuğu görülmektedir. 2013-2016 döneminde ise yolcu sayısındaki artış \%1,15 düzeyinde gerçekleşmiştir. Amerikan Airlines şirketinden sonra yolcu sayısı en çok artan şirket \%115'lik oran ile Türk Hava Yolları olup ikinci sırada yer almaktadır. Ancak Türk Hava Yolları 2010-2016 döneminde herhangi bir şirket birleşmesi yaşamamıştır. Bu nedenle aynı dönemde Türk Hava Yollarının yolcu sayısındaki artışın daha yüksek oranda olduğu ifade edilebilir. Air Berlin şirketinin yolcu sayısı ise aynı dönemde \%17 oranında azalmıştır. Havayolu şirketlerinin yolcu sayısının artmasındaki önemli unsurlardan biride uçak sayılarındaki artıştır. Havayolu şirketleri yolcu sayılarını artırmak için uçak sayılarını veya yolcu doluluk oranlarını artırmaları gerekmektedir. Yolcu doluluk oranının maksimum kapasiteye ulaşmasıyla yolcu sayısında kısmi bir yükseliş olmaktadır. Bu nedenle havayolu şirketleri daha çok yolcu taşımak için uçak sayılarını artırmakta diğer bir ifadeyle filolarını genişletmektedir. Havayolu şirketlerinin filolarındaki uçak sayılarının yüksek oluşu şirketlerin daha fazla ülkeye veya şehre sefer düzenlemesini sağlayarak uçuş ağını genişletmektedir. $\mathrm{Bu}$ nedenle havayolu şirketlerinin filolarındaki uçak sayılarının verilmesinin yararlı olacağ düşünülmektedir. Örneklemdeki havayolu şirketlerinin 2010-2016 dönemi uçak sayıları Tablo 5 'de verilmiştir.

Tablo 5. Havayolu şirketlerinin uçak sayıları

\begin{tabular}{lccccccc}
\hline Havayolu Firmaları & $\mathbf{2 0 1 0}$ & $\mathbf{2 0 1 1}$ & $\mathbf{2 0 1 2}$ & $\mathbf{2 0 1 3}$ & $\mathbf{2 0 1 4}$ & $\mathbf{2 0 1 5}$ & $\mathbf{2 0 1 6}$ \\
\hline Air Asia & 53 & 57 & 64 & 72 & 81 & 80 & 77 \\
Air Berlin Group & 169 & 170 & 155 & 140 & 149 & 153 & 139 \\
Air China & 393 & 432 & 461 & 497 & 540 & 603 & 623 \\
Air France - KLM & 593 & 609 & 601 & 611 & 571 & 564 & 552 \\
Air New Zeland & 99 & 102 & 102 & 106 & 106 & 103 & 103 \\
ANA Holdings & 210 & 222 & 226 & 238 & 231 & 255 & 257 \\
American Airlines & 280 & 299 & 254 & 970 & 983 & 946 & 930 \\
Cathay Pacific & 167 & 175 & 187 & 181 & 188 & 201 & 202 \\
China Eastern Airlines & 355 & 377 & 416 & 478 & 515 & 551 & 596 \\
China Southern Airlines & 422 & 444 & 491 & 561 & 612 & 667 & 702 \\
Delta Airlines & 1.355 & 1.325 & 1.285 & 1.275 & 1.271 & 1.291 & 1.301 \\
Easyjet & 196 & 218 & 214 & 217 & 226 & 241 & 257 \\
Emirates & 142 & 148 & 169 & 197 & 217 & 231 & 251 \\
Lufthansa & 710 & 696 & 627 & 622 & 615 & 600 & 617 \\
Qantas Airways & 254 & 283 & 308 & 312 & 308 & 299 & 303 \\
Ryanair & 232 & 272 & 294 & 305 & 297 & 308 & 341 \\
Singapore Airlines & 108 & 108 & 133 & 100 & 103 & 101 & 102 \\
Southwest Airlines & 548 & 698 & 694 & 681 & 665 & 704 & 723 \\
Turkish Airlines & 153 & 179 & 202 & 233 & 261 & 299 & 334 \\
United Airlines & 655 & 645 & 629 & 702 & 691 & 715 & 737 \\
\hline Toplam & $\mathbf{7 . 0 9 4}$ & $\mathbf{7 . 4 5 9}$ & $\mathbf{7 . 5 1 2}$ & $\mathbf{8 . 4 9 8}$ & $\mathbf{8 . 6 3 0}$ & $\mathbf{8 . 9 1 2}$ & $\mathbf{9 . 1 4 7}$ \\
\hline & & & & & & & \\
\hline & & & & & & \\
& & & & & &
\end{tabular}

Tablo 5 incelendiğinde örneklemdeki havayolu şirketlerinin 2010 y1lı ile 2016 yılları arasında uçak sayılarının ortalama \%28,94 oranında arttı̆̆ 1 görülmektedir. Filosunda en fazla artış \%232'lik oran ile Amerikan Airlines havayolu şirketinde görülmüştür. Birleşmeden sonra şirketin filosunda büyük bir artış olmuştur. \%118'lik bir artış ile filosunda en yüksek artış görülen ikinci havayolu şirketi ise Türk Hava Yollarıdır. Türk Hava Yollarının satış gelirleri ile uçak sayısındaki artışın birbirlerine paralellik gösterdiği görülmektedir. Aynı dönemde Air Berlin havayolu şirketinin filosunda ise \%17 oranında bir daralma görülmektedir. Air FranceKLM, Delta Airlines, Lufthansa ve Singapore Airlines havayolu şirketlerinin aynı dönemde uçak sayısı azalmış olmasına rağmen yolcu sayılarında artış olmuştur. Havayolu şirketleri koltuk arzı sabitken daha çok yolcu taşıyarak yolcu doluluk oranlarını yükseltmiş olabileceği düşünülmektedir. 
Havayolu şirketlerinin mevcut koltuk arzı ile yolcu doluluk oranının maksimum düzeye çıkarılması arzu edilmektedir. Filodaki uçak sayısının artışından daha çok koltuk doluluk oranının artmasıyla havayolu şirketlerinin verimlilik düzeyinin artması beklenmektedir. Çünkü yolcu doluluk oranı arttıkça havayolu şirketlerinin faaliyet kaldıracı etkisiyle marjinal gelirleri artabilmektedir. Böylece faaliyet kaldıracı ve koltuk doluluk oranlarının artmasıyla şirketlerin verimliliklerinde artması beklenmektedir.

\section{Havayolu Şirketlerinde Faaliyet Kaldıracı}

Faaliyet kaldıracı, satış gelirleri ile faaliyet kârı arasındaki ilişkiyi ifade etmekte olup satışlara göre sabit ve değişken maliyetlerinin büyüklüğünün bir fonksiyonu olarak tanımlanmaktadır (Stowe ve Ingene, 1984: 233). Faaliyet kaldıracındaki artış, birim başına değişken giderdeki azalış ve/veya sabit giderdeki artış ile olmaktadır (Percival, 1974: 223). Dolayısıyla sabit giderlerin operasyonel giderler içindeki payının artırılması faaliyet kaldıraç derecesini yükseltmektedir (Dran and John, 2001: 88). Faaliyet kaldıraç derecesi, talebin fiyatı esnekliği ile pozitif yönde olduğu ifade edilmiştir (Stowe ve Ingene, 1984: 233-234). Ayrıca sabit ve değişken giderlerin, üretim, operasyon ve finansal karar alma mekanizmaları üzerinde önemli bir etkisi vardır (Shrieves, 1981: 701).

İşletmelerin karşılaşabileceği riskler genel olarak sistematik ve sistematik olmayan riskler olarak ikiye ayrılmaktadır. Faaliyet riski sistematik olmayan risklerden biri olup sıfır borcu olan bir işletmenin bu riskle karşılaşması dahi muhtemeldir (Brigham ve Houston, 2014: 443). Ayrıca işletmelerin kendisinden kaynaklanmayan sistematik riskin, finansal kaldıraç ve faaliyet kaldıracı üzerinde etkili olabileceği ifade edilmektedir (Gahlon ve Gentry, 1982: 15-16). Şirketlerin belirsizlik altında henüz gerçekleşmemiş satış gelirleri için önceden sabit giderleri taahhüt etmesi, nakit akışlarının özkaynaklara olan riskini artırmakta, bu durum kaldıraç etkisi olarak ifade edilmektedir (Huffman, 1983: 197). Yüksek tutarlarda borçlanma, sermaye maliyetini artıracağı gibi şirketlerin karşılaşacakları finansal riski de artırabilmektedir (O'Brien ve Vanderheiden, 1987: 50). Faaliyet kaldıracı nedeniyle karşılaşılan herhangi bir olumsuzluk şirketin faaliyet riskinin artmasına neden olabilmektedir (Alaghi, 2012: 1095). Havayolu şirketlerinde finansal kiralama işlemi, kısa ve uzun vadeli borçları yükselttiğinden şirketlerin kredi ödeme riskiyle karşılaşma olasılığ yükselmekte; faaliyet kiralaması yapılması durumunda ise sabit bir yükümlülük olmadığından şirketlerin finansal riskini azaltmaktadır (Erickson ve Trevino, 1994: 71). Faaliyet kaldıraç derecesi, finansal kiralama işlemiyle artacağından şirketlerin daha yüksek tutarlarda satış yapması mümkün olabilmektedir. Finansal kiralama sözleşmeleri şirketlerin aktif ve pasifini artırmakta, finansal performansını da olumlu yönde etkilemektedir (Fitó vd., 2014: 364).

Tutarı yüksek sabit giderler ve yüksek faaliyet kaldıracıyla faaliyet gösteren havayolu şirketlerinin devamlılığının sağlanması gelirindeki sürekliliğe bağlıdır (Nicolau ve Santa-María, 2012: 44). Faaliyet kaldıracı ile finansal kaldıracın sermaye yapısından etkilendiği ifade edilmektedir (Prezas, 1987: 39). İşletmeler yüksek tutarlı duran varlık yatırımlarını yabancı kaynaklarla finanse ettiklerinde sermaye maliyeti yükselebilmektedir. Bu durumda işletme kapasiteyi artırdığından eskisinden daha yüksek tutarlı sabit giderleri olacağından, bu giderlerin artmasından dolayı faaliyet kaldıracı riski de yükselmektedir (Lev, 1974: 627). Şirketlerin sabit aktiflerindeki (duran varlıklar) artış ile faaliyet kaldıracı arasında anlamlı bir ilişki olduğu ifade edilmektedir (Lev, 1974: 638). Satışlardaki değişime bağlı olarak faaliyet kârındaki göreceli değişimin, faaliyet kârı ile satışlar arasında ilişki üzerinde sabit maliyetlerin etkisi olabileceğini düşündürmektedir (Schönenberger, 2014: 8). Bir şirketin giderlerinin tümünün değişken olması durumunda faaliyet kaldıracından söz etmek mümkün değildir (Akgüç, 1998: 136). Faaliyet Kaldıraç Derecesi hesaplanırken kullanılan formül aşağıda verilmiştir (Ercan ve Ban, 2012: 247):

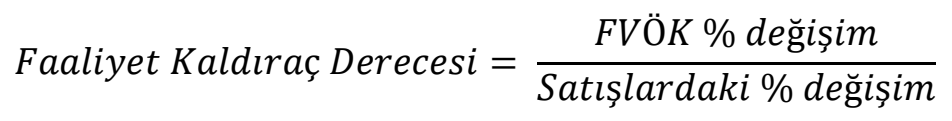


Faiz ve vergi öncesi kârdaki \% değişimin, satışlardaki \% değişime bölünmesiyle hesaplanmaktadır. FVÖK yüzdelik değişim ne kadar yüksek, satışlardaki değişim ne kadar az olursa faaliyet kaldıraç derecesi o kadar yüksek olmaktadır.

Örneklemdeki havayolu şirketlerinin 2010-2016 dönemi Faaliyet Kaldıraç Dereceleri hesaplanarak Tablo 6'da verilmiştir.

Tablo 6. Havayolu şirketlerinin faaliyet kaldıraç dereceleri

\begin{tabular}{lccccccc}
\hline Airline Companies & $\mathbf{2 0 1 0}$ & $\mathbf{2 0 1 1}$ & $\mathbf{2 0 1 2}$ & $\mathbf{2 0 1 3}$ & $\mathbf{2 0 1 4}$ & $\mathbf{2 0 1 5}$ & $\mathbf{2 0 1 6}$ \\
\hline Air Asia & 0,62 & 0,73 & $-1,17$ & $-4,81$ & $-0,72$ & 5,72 & 10,81 \\
Air Berlin Group & $-7,04$ & 261,02 & $-64,58$ & 112,72 & 77,87 & $-2,34$ & $-16,27$ \\
Air China & 0,95 & $-1,24$ & 3,72 & 18,43 & 5,94 & 14,05 & 2,81 \\
Air France - KLM & 12,62 & 0,90 & 0,45 & 35,42 & $-3,23$ & 7,97 & 3,66 \\
Air New Zeland & $-0,24$ & $-0,87$ & 2,40 & 8,64 & 16,13 & 2,49 & 5,38 \\
ANA Holdings & 4,29 & 20,21 & 4,07 & 1,04 & $-1,72$ & 1,42 & 4,39 \\
American Airlines & $-11,55$ & $-54,19$ & $-31,22$ & 111,28 & 3,42 & $-11,82$ & 7,50 \\
Cathay Pacific & 3,48 & $-3,05$ & $-25,95$ & $-17,23$ & 2,77 & 116,04 & 18,21 \\
China Eastern & 12,77 & $-0,20$ & 0,19 & $-1,68$ & 23,95 & $-1,27$ & 2,60 \\
China Southern Airlines & 2,88 & $-0,54$ & 0,38 & $-3,24$ & 7,38 & 23,53 & $-2,26$ \\
Delta Airlines & 12,20 & $-0,93$ & 2,39 & 18,72 & $-5,12$ & 299,38 & 4,16 \\
Easyjet & 16,40 & 3,41 & 1,98 & 4,78 & 2,68 & 5,24 & 76,12 \\
Emirates & 176,35 & 1,37 & $-1,91$ & 2,82 & 2,81 & 4,01 & $-7,57$ \\
Lufthansa & 3,41 & $-0,96$ & 0,98 & 241,87 & 1769,44 & 13,94 & 21,31 \\
Qantas Airways & $-1,92$ & 0,94 & $-1,29$ & $-30,23$ & $-29,38$ & 138,36 & 12,48 \\
Ryanair & 212,50 & 1,00 & 1,39 & 1,25 & $-2,69$ & 4,76 & 2,57 \\
Singapore Airlines & $-17,31$ & $-22,41$ & $-34,39$ & 16,82 & 13,58 & 27,45 & $-30,72$ \\
Southwest Airlines & 4,65 & $-0,17$ & 1,85 & 14,85 & 8,74 & 7,49 & $-3,20$ \\
Turkish Airlines & $-1,96$ & 41,18 & 0,28 & $-0,41$ & 0,54 & 2,75 & $-101,34$ \\
United Airlines & 30,94 & $-1,52$ & 85,02 & 32,90 & 29,62 & $-19,74$ & 5,33 \\
\hline & & & & & & &
\end{tabular}

Havayolu şirketlerinin faaliyet kaldıraç dereceleri incelendiğinde Lufthansa havayolu şirketinin, 2014 yılında 1769,44 ile en yüksek faaliyet kaldıraç derecesine sahip olduğu görülmektedir. En düşük faaliyet kaldıraç derecesi ise 2016 yılında -101,34 ile Türk Hava Yollarında görülmüştür. Faaliyet kaldıraç derecesinin negatif değer alması şirketlerin FVÖK veya satışlarındaki azalışlardan kaynaklanabilmektedir. Cari dönem satış gelirleri bir önceki döneme göre azalmışsa faaliyet kaldıraç derecesi negatif değer alabilmektedir.

\section{Literatür Taraması}

$\mathrm{Bu}$ kısımda faaliyet kaldıracı ve satış gelirleri arasındaki ilişkiyi inceleyen ulusal ve uluslararası literatürdeki çalışmalara yer verilmek istenmiş, ancak konuyla doğrudan ilgili yapılmış çalışmaya rastlanılmamıştır. Bu nedenle modeldeki değişkenlerle ilgili yapılmış çalışmalar araştırılmış; finansal kiralama giderleri, faaliyet kaldıracı, kârlılık ve satış gelirleri üzerine yapılmış çalışmalara bu bölümde yer verilmiştir.

Dayı ve Ulusoy (2018), Türk Hava Yolları ile dünyadaki diğer havayolu şirketlerinin finansal performanslarını karşılaştırmışlardır. Uygulamada oran analizi ile minimum örten ağaç yaklaşımı kullanılmıştır. 19 havayolu şirketinin 2008-2014 dönemi verilerinden hesaplanan 8 orandan oluşan veriler minimum örten ağaç yöntemiyle analiz edilmiştir. Analiz sonucuna göre Türk Hava Yollarının kârlılığı, satış gelirleri ve toplam aktiflerinin her yıl büyüdügüu, Aktif ve Özsermaye Kârlılık oranları örneklemdeki şirketler ile karşılaştırıldığında ilk iki sırada yer 
aldığı, şirketin finansal performansının örneklemdeki şirketlerden daha başarılı olduğu ifade edilmiştir.

Bourjade vd. (2017) finansal kiralama giderlerinin kârlılık üzerine etkisini incelemiştir. Çalışmada 1996-2011 dönemine ait 73 havayolu şirketinin verileri kullanılmıştır. Havayolu şirketlerinin finansal kiralama giderlerinin optimal tutara ulaşıncaya kadar kârı artırdığı, optimal tutardan sonra yapılan finansal kiralama giderlerinin ise marjinal kârı azalttığı tespit edilmiştir.

Dayı ve Esmer (2017) sivil havacılık yönetiminde finansal kiralama işlemlerinin aktif kârl1lık ve özsermaye kârlılık üzerine etkisini incelemiştir. Avrupa da faaliyet gösteren 6 havayolu şirketinin 2008-2012 dönemi mali tablo ve operasyonel bilgileri rasyo analizi yönteminde kullanarak analiz edilmiştir. Analiz bulgularında faaliyet kaldıraç derecesinin aktif ve özsermaye kârlılığı üzerinde önemli bir etkiye neden olmadığ ifade edilmiştir.

Abbruzzo vd. (2016) İtalyan havayolu şirketlerinin finansal ve faaliyet performansını inceledikleri çalışmada, 10 havayolu şirketinin 7 yıllık verilerini RCON (V, E) modelinde kullanmışlardır. Şirketlerin uçuş sayısındaki artış ile yolcu sayısının, satış gelirlerinin ve kârlılıklarının arttığ tespit edilmiştir.

Richardson vd. (2014) havayolu şirketlerinin finansal kiralama sözleşmelerinin Amerikalı havayolu şirketlerinin finansal performansı üzerindeki etkisini incelemiştir. Uygulamada 23 havalimanı ve havayolu şirketinin verileri kullanılmıştır. İçerisinde cari oran, borç oranı, faaliyet kârlılığı gibi oranlarında olduğu 21 değişkenin 2011-2012 dönemi verileri Benchmarking ve istatistiki yöntemlerle analiz edilmiştir. Finansal kiralama işleminin havayolu şirketlerinin finansal performansını olumlu yönde etkilediği tespit edilmiştir.

Nicolau vd. (2012) sivil havacılık sektöründe faaliyet gösteren şirketlerin yüksek tutarlarda inovasyona dayalı sabit duran varlık yatırımı yapmalarının şirketlerin piyasa değeri üzerine etkisini incelemişlerdir. Çünkü havayolu şirketleri yüksek tutarlarda sabit aktifi ve yüksek oranlarda faaliyet kaldıracı olduğundan şirketlerin satış gelirlerindeki devamlılık faaliyetlerini sürdürebilmeleri için önemli olduğu ifade edilmiştir. Uygulama İspanya'daki havayolu şirketleri üzerinde yapılmıştır. İnovasyona dayalı gelişmiş tüketici segmentasyonun, satışlar üzerinde sabit maliyetlerden daha büyük bir etkiye sahip olduğunu ve havayolu şirketlerinin faaliyet risklerinin düşmesinde etkili olabileceği ifade edilmektedir.

Lee ve Hooy (2012) Kuzey Amerika, Asya ve Avrupa kıtasındaki havayolu şirketlerinin finansal risklerine etki eden faktörleri araştırmıştır. Kuzey Amerikalı şirketlerin risk düzeyleri ile faaliyet kaldıracı ve kârlılıkları arasında pozitif yönde bir ilişki olduğu tespit edilmiştir. Avrupa ve Asya kıtasındaki şirketlerin risk düzeyleri ile faaliyet kaldıracı arasında pozitif yönde bir ilişkinin olduğu, kârlılık ile önemli düzeyde negatif yönde ilişkinin olduğu ifade edilmiştir. Asya kıtasındaki şirketlerin sistematik risklerinin aktif büyüklükleriyle ilişkili olduğu belirtilmektedir. Ayrıca Asya kıtasındaki şirketlerin faaliyet kaldıraç derecelerinin -\%2670 ile $\% 1851$ arasında değiştiği ifade edilmektedir.

Gavazza (2010), finansal kiralama işleminin havayolu şirketlerinin finansmanında önemli olduğunu, yüksek tutarlı uçakların finansal kiralamayla temin edilmesi gerektiğini belirtmektedir. Finansal kiralama işleminin havayolu şirketlerinin likiditesini artırdı̆̆ını, özellikle faaliyet kiralamasının daha kısa süreli ama daha faydalı olduğunu, finansal kiralama işlemlerinin uzun vadeli olduğunu ve finansal kiralama sözleşmelerinde kâr marjının uçak satış kâr marjının çok üstünde olduğunu, bu nedenle daha düşük oranlarda kâr marjının belirlenmesi gerektiğini belirtmiştir.

Lee ve Jang (2007) 16 havayolu şirketinin 1997-2002 dönemi verilerini kullanarak havayolu şirketlerinde riske etki eden faktörleri incelemiştir. Havayolu şirketlerinde risk ile şirketlerin kârlılık, büyüme ve güvenlik oranı arasında negatif; kaldıraç ve firmanın büyüklüğü arasında pozitif yönde ilişki olduğu tespit edilmiştir. 
Oum vd. (2000) havayolu şirketlerinde talebin esnek ve belirsiz olmasından dolayı şirketlerin filosunda ne kadar uçak olması gerektiği saptamanın zor olduğunu, bununla baş edebilmek için finansal veya faaliyet kiralaması yapıldığını, şirketlerin sahip oldukları ve kiraladıkları uçakların optimum sayıda olması gerektiği ifade edilmiştir. Uygulamada 23 büyük havayolu şirketinin 1986-1993 dönemine ait verileri kullanılmıştır. Kısa dönemde finansal kiralama veya faaliyet kiralaması işleminde havayolu şirketi ile finansal kiralama şirketi arasında riskin paylaşımı veya değişimi olduğu ifade edilmiştir. Yolcu sayısındaki artışa paralel havayolu şirketi kiralama işlemiyle daha fazla yolcu taşımakta, ancak yolcu sayısındaki düşüş ile uçak sayısında fazlalık oluşmaktadır. Bu nedenle havayolu şirketlerinin maliyeti düşürerek satış gelirlerini artırmaları için optimum düzeyde finansal kiralamayla uçak temin etmeleri önerilmektedir.

Gritta vd. (1994) havayolu şirketlerinin finansal kiralama yöntemini sıkça tercih ettiklerini, finansal kiralama yöntemiyle 1970'li yıllarda yüksek tutarlarda uzun vadeli borçlandıklarını ifade etmiştir. Bazı finansal kiralama işlemlerinin de bilançoda olumlu etkilere neden olduğu ifade edilmiştir. Ayrıca Gritta (1994), 1969 yılında o zamanki adıyla Hava Taşımacılar Birliğinin (Air Transport Association-ATA) raporuna göre uçak filosunun \%13,9'luk kısmının finansal kiralama yöntemiyle temin edildiği belirtmiştir.

Erickson ve Trevino (1994), finansal kiralamanın kısa ve uzun vadeli borçları artırarak kredi riskini yükselttiğini ifade etmiştir. Uygulamada 43 havayolu şirketinin 1985-1990 dönemine ait verilerinden yararlanılarak hesaplanan çeşitli oranlar ile panel veri analizi yapılmıştır. Finansal kiralama tutarının artmasıyla büyüyen varlıkların arasında ters yönlü ilişkinin olduğu ve kârlılık ile finansal kiralama arasında anlamlı bir ilişki olmadığı ifade edilmiştir.

\section{Materyal ve Yöntem}

Çalışmanın amacı havayolu şirketlerinin faaliyet kaldıraç derecesi ile satış gelirleri arasındaki ilişkinin incelenmesidir. Örneklem her kıtadan bir şirket olmak üzere verisine ulaşılabilen 20 havayolu şirketinden oluşmaktadır. 20 havayolu şirketinin 2010-2016 dönemine ait 7 yıllık verileri panel veri en küçük kareler yöntemiyle analiz edilmiştir. Çalışmada kullanılan değişkenler, nitelikleri, frekans düzeyleri ve veri kaynakları Tablo 7'de verilmiştir.

Tablo 7. Çalışmanın veri seti

\begin{tabular}{lccc}
\hline Değişkenler & Nitelik & Frekans & Kaynak \\
\hline Satış Gelirleri & Bağımlı & Yıllık & Mali Tablo \\
Faaliyet Kaldıraç Derecesi & Bağımsız & Yıllık & Mali Tablo \\
Finansal Kiralama Giderleri & Bağımsız & Yıllık & Mali Tablo \\
Aktif Kârlılık Oranı (ROA) & Bağımsız & Yıllık & Mali Tablo \\
Özsermaye Kârlılık Oranı (ROE) & Bağımsız & Yıllık & Mali Tablo \\
\hline
\end{tabular}

Satış gelirleri modelde bağımlı değişken olarak kullanılmıştır. Faaliyet kaldıracı derecesi, Faiz ve Vergi Öncesi Kârdaki (FVÖK) yüzdelik değişimin, satışlardaki yüzdelik değişime oranlanmasıyla hesaplanmıştır.

Faaliyet kaldıraç derecesi, finansal kiralama giderleri, ROA ve ROE bağımsız değişken olarak modelde yer almaktadır. Çalışmada kullanılan tüm veriler, şirketlerin bağımsız denetiminden geçmiş mali tablolardan elde edilmiştir. Mali tablolardan elde edilen bazı veriler Microsoft Excel programından yararlanılarak hesaplanmıştır. Şirketin finansal performansını incelemek için ROA ve ROE değişkenlerinin kullanıldığı literatürde yapılmış çalışmalarda görülmektedir. Havayolu şirketlerinin yüksek tutarlı varlıklarının verimli kullanılıp kullanılmadığını test etmek için ROA; özsermaye verimliliğinin değerlendirilmesi içinde ROE modele dahil edilmiştir. Çünkü havayolu şirketleri kurulduğu ilk yıllarda uçak satın alırken 
özkaynaklar ağırlıklı finansman kaynakları kullanacağından, havayolu şirketlerinin satış gelirleri ile ROE ilişkisinin değerlendirilmesinin yararlı olacağı düşünülmektedir.

Faaliyet kaldıraç derecesi satış gelirleri üzerinde etkisi olduğundan, mevcut arz sabitken, daha fazla yolcu taşımak havayolu şirketlerinin gelirlerini artırmaktadır. Ayrıca havayolu şirketleri uçuş yaklaştıkça uçak biletlerini çok yüksek fiyatlardan satabilmektedir. Bir diğeri ise koltuk doluluk oranındaki artış olup bazen arzı artırmak için uçakların sayısının artırıldığı da görülmektedir. Ancak koltuk doluluk oranı \%90'nın üstünde olan bir havayolu şirketi, yolcu sayısını artırmak istediğinde uzun bir süre beklemesi gerekebilmektedir. Çünkü uçak satın almak için sipariş vermek ve teslimat için sıraya girmek gerekmektedir. Ancak kısa vadede faaliyet kiralaması yöntemi ile yolcu sayısını artırmakta mümkündür.

Faaliyet kiralamasıyla uçak temin etmek kısa dönem için satın almaktan daha rasyonel bir karar olarak görülmektedir. Çünkü uçak satın aldıktan sonra arz edilen koltuk sayısı artmakta; yolcu sayısında görülen olası bir azalış ise yolcu doluluk oranını düşürmektedir. $\mathrm{Bu}$ nedenle faaliyet kiralaması kısa vadeli uçak ihtiyacı için havayolu şirketlerinin sıkça başvurduğu bir yöntemdir. Bunun yanı sıra yüksek fiyatlı yolcu uçaklarını satın almak için yeterli sermayesi olmayan şirketler, finansal kiralama yöntemiyle taksit ödeyerek uçak sahibi olabilmektedir. Böylece kısa ve uzun vadeli banka kredisi kullanılmadığından, finansal risk düzeyi düşmektedir. Ayrıca şirketlerin finansal kiralama yöntemini kullanarak kredibilitesi düşmediğinden, ihtiyaç duyulduğunda bankadan kredi kullanılması da mümkündür.

Finansal kiralama yöntemiyle finansman havayolu sektöründe sıkça kullanılmaktadır. Havayolu şirketleri yüksek tutarlarda sermayeyi uçaklara bağlamaktan kaçınmakta ve banka kredisi kullanarak uçak satın alma yolunu tercih etmemektedir. Çünkü kullanılan kredi pasifte yer alacağından, kredi kuruluşlarının nazarında şirketin kredibilitesi düşebilecektir. Bu nedenle finansal kiralama yönteminde ise uçağın bedeli taksit taksit ödenmekte, banka kredisinden daha esnek olmakta, gider olarak vergi matrahından düşülebilmektedir. Bu nedenle şirketler finansal kiralama yöntemini tercih etmektedir. Örneğin Cathay Pasific filosunun \%56,3'ü (12/2005), Air China \%36,8'i (06/2004), Air France KLM \%16,9'u (03/2006) ve United Airlines \%12,4'ü (12/2005) finansal kiralamayla temin edilen uçaklardan oluşmaktadır (Morrell, 2007: 197).

$\mathrm{Bu}$ nedenlerden dolayı birçok havayolu şirketi finansal kiralama yöntemini kullanarak uçak filosunu güçlendirmekte ve arz edilen yolcu koltuk sayısını artırmaktadır. Finansal kiralama giderlerinin yolcu sayısında ve satış gelirleri üzerinde doğrudan etkisi olduğundan modele dâhil edilmiştir. Faaliyet kaldıracı sabit giderleri yüksek olan şirketlerde, sabit giderin karşılanmasından sonra yüksek tutarlarda kâr etmelerini sağlamaktadır. Faaliyet kaldıracının yüksekliği havayolu şirketlerinin kârını ve kârlılığını doğrudan etkilemektedir. Dayı ve Esmer (2017a), havayolu şirketlerinin kârlılıklarını incelemek için modellerinde aktif kârlılık oranı (ROA) ve Özsermaye kârlılık oranlarını da (ROE) kullanmışlardır. Havayolu şirketlerinin net kârındaki artış kârlılık oranlarına olumlu yönde yansımıştır. Şirketlerin toplam aktifinin yüksek tutarlarda olmasından dolayı ROA düşük hesaplanabilmektedir. ROE, şirketlerin özsermayelerini verimli kullanıp kullanmadıklarının tespitinde önemli bir göstergedir. Özellikle negatif özkaynakları olan şirketler örneklemde olduğundan bu oran ile satış gelirleri arasındaki ilişskisinin incelenmesinin yararlı olacağı düşünülmektedir. Şirketlerin satış gelirleri yükseldiğinde, net kâr ve özsermaye kârlılığının da yükselmesi beklenir.

Panel veri analizi, örneklemde yer alan birimlerin ve zaman serilerinin birden fazla olmas1 durumunda kullanılmaktadır (Hsiao, 2014: 1). Yatay ve dikey kesitlerin birlikte yer aldığı çok sayıda hane, ülke veya firmaya ait verilerin kullanılabildiği panel veri analizi, regresyon, rassal etkiler, sabit etkiler, dinamik gibi birçok çeşidi vardır (Bayraktutan \& Demirtaş, 2011: 5). Panel veri yönteminde regresyon analizi yapılırken, havuzlanmış, rassal etkiler ve sabit etkiler olmak üzere 3 yöntemden biri kullanılmaktadır (Korkmaz vd., 2010: 100). Hausman Testi sonucuna göre rassal etkiler, sabit etkiler veya havuzlanmış en küçük 
kareler yöntemlerinden hangisiyle panel veri analizinin yapılacağına karar verilmektedir. Çalışmanın uygulamasındaki tüm analizler STATA 15 paket programı kullanılarak yapılmıştır.

\section{Bulgular ve Tartışma}

Bu kısımda ilk olarak modeldeki değişkenler ile yolcu ve uçak sayıları arasındaki korelasyon ilişkisi test edilmiştir. Korelasyon testinden sonra modelin tanımlayıcı istatistiklerine yer verilmiştir. Hausman ve Breusch-Pagan Langrange Multiplier Testi yapılarak analizin hangi yöntemle yapılacağına karar verilmiştir. Son olarak panel veri en küçük kareler yöntemi uygulanarak analizin bulguları değerlendirilmiştir. Korelasyon testi sonuçları Tablo 8'de verilmiştir.

Tablo 8. Korelasyon testi sonuçları

\begin{tabular}{|c|c|c|c|c|c|c|c|c|}
\hline & & $\begin{array}{c}\text { Satış } \\
\text { Gelirleri }\end{array}$ & $\begin{array}{c}\text { Faaliyet } \\
\text { Kaldıracı }\end{array}$ & $\begin{array}{c}\text { Finansal } \\
\text { Kiralama } \\
\text { Giderleri } \\
\end{array}$ & ROA & ROE & $\begin{array}{l}\text { Yolcu } \\
\text { Sayısı }\end{array}$ & $\begin{array}{l}\text { Uçak } \\
\text { Sayısı }\end{array}$ \\
\hline \multirow{3}{*}{ Satış Gelirleri } & $\begin{array}{l}\text { Pearson } \\
\text { Correlation }\end{array}$ & 1 & 0,113 & $0,475^{\text {** }}$ & 0,142 &,- 012 & $0,634_{*}^{*}$ & $0,702^{*}$ \\
\hline & Sig. (2-tailed) & & 0,182 & 0,000 & 0,094 & 0,887 & ,000 & 0,000 \\
\hline & $\mathrm{N}$ & 140 & 140 & 140 & 140 & 140 & 138 & 140 \\
\hline \multirow{2}{*}{$\begin{array}{l}\text { Faaliyet } \\
\text { Kaldıracı }\end{array}$} & $\begin{array}{l}\text { Pearson } \\
\text { Correlation }\end{array}$ & 0,113 & 1 & 0,075 &,- 028 &,- 077 & 0,097 & 0,076 \\
\hline & $\begin{array}{l}\text { Sig. (2-tailed) } \\
\mathrm{N}\end{array}$ & $\begin{array}{r}0,182 \\
140\end{array}$ & 140 & $\begin{array}{r}0,379 \\
140\end{array}$ & $\begin{array}{r}0,740 \\
140\end{array}$ & $\begin{array}{r}0,366 \\
140\end{array}$ & $\begin{array}{r}0,257 \\
138\end{array}$ & $\begin{array}{r}0,369 \\
140\end{array}$ \\
\hline \multirow{2}{*}{$\begin{array}{l}\text { Finansal } \\
\text { Kiralama } \\
\text { Giderleri }\end{array}$} & $\begin{array}{l}\text { Pearson } \\
\text { Correlation }\end{array}$ & $0,475^{* *}$ & 0,075 & 1 &,- 128 & 0,080 & $0,387^{*}$ & $0,457^{*}$ \\
\hline & $\begin{array}{l}\text { Sig. (2-tailed) } \\
\mathrm{N}\end{array}$ & $\begin{array}{r}0,000 \\
140\end{array}$ & $\begin{array}{r}0,379 \\
140\end{array}$ & 140 & $\begin{array}{r}0,133 \\
140\end{array}$ & $\begin{array}{r}0,345 \\
140\end{array}$ & $\begin{array}{r}0,000 \\
138\end{array}$ & $\begin{array}{r}0,000 \\
140\end{array}$ \\
\hline \multirow{2}{*}{ ROA } & $\begin{array}{l}\text { Pearson } \\
\text { Correlation }\end{array}$ & 0,142 &,- 028 &,- 128 & 1 & 0,101 & $0,193^{*}$ & $0,171^{*}$ \\
\hline & $\begin{array}{l}\text { Sig. (2-tailed) } \\
\mathrm{N}\end{array}$ & $\begin{array}{r}0,094 \\
140 \\
\end{array}$ & $\begin{array}{r}0,740 \\
140 \\
\end{array}$ & $\begin{array}{r}0,133 \\
140 \\
\end{array}$ & 140 & $\begin{array}{r}0,235 \\
140 \\
\end{array}$ & $\begin{array}{r}0,023 \\
138 \\
\end{array}$ & $\begin{array}{r}0,044 \\
140 \\
\end{array}$ \\
\hline \multirow{2}{*}{ ROE } & $\begin{array}{l}\text { Pearson } \\
\text { Correlation }\end{array}$ &,- 012 &,- 077 & 0,080 & 0,101 & 1 & 0,115 & ,069 \\
\hline & $\begin{array}{l}\text { Sig. (2-tailed) } \\
\text { N }\end{array}$ & $\begin{array}{r}0,887 \\
140\end{array}$ & $\begin{array}{r}0,366 \\
140\end{array}$ & $\begin{array}{r}0,345 \\
140\end{array}$ & $\begin{array}{r}0,235 \\
140\end{array}$ & 140 & $\begin{array}{r}0,178 \\
138\end{array}$ & $\begin{array}{r}0,415 \\
140\end{array}$ \\
\hline \multirow{2}{*}{ Yolcu Sayısı } & $\begin{array}{l}\text { Pearson } \\
\text { Correlation }\end{array}$ & $0,634^{* *}$ & 0,097 & $0,387^{* *}$ & $0,193^{*}$ & 0,115 & 1 & $0,935^{*}$ \\
\hline & $\begin{array}{l}\text { Sig. (2-tailed) } \\
\mathrm{N}\end{array}$ & $\begin{array}{r}0,000 \\
138\end{array}$ & $\begin{array}{r}0,257 \\
138\end{array}$ & $\begin{array}{r}0,000 \\
138\end{array}$ & $\begin{array}{r}0,023 \\
138\end{array}$ & $\begin{array}{r}0,178 \\
138\end{array}$ & 138 & $\begin{array}{r}0,000 \\
138\end{array}$ \\
\hline \multirow{3}{*}{ Uçak Sayısı } & $\begin{array}{l}\text { Pearson } \\
\text { Correlation }\end{array}$ & $0,702^{* *}$ & 0,076 & $0,457^{* *}$ & $0,171^{*}$ & 0,069 & $0,935^{*}$ & 1 \\
\hline & Sig. (2-tailed) & 0,000 & 0,369 & 0,000 & 0,044 & 0,415 & 0,000 & \\
\hline & $\mathrm{N}$ & 140 & 140 & 140 & 140 & 140 & 138 & 140 \\
\hline
\end{tabular}

**. Korelasyon 0.01 anlamlılık düzeyinde (2-tailed).

*. Korelasyon 0.05 anlamlılık düzeyinde (2-tailed).

Korelasyon testi sonuçları incelendiğinde satış gelirleri ile bağımsız değişkenler arasındaki korelasyon ilişkisinin düşük olduğu görülmektedir. Modeldeki değişkenler arasındaki korelasyon testi sonuçlarına göre en yüksek korelasyon, satış gelirleri ile finansal kiralama giderleri arasında 0,475 oranında gerçekleşmiştir. Ayrıca modelde yer almayan ancak havayolu şirketlerinin verimliliğini değerlendirmek için kullanılan yolcu ve uçak sayısı değişkenlerinin arasında \%93,5 oranında korelasyon olduğu görülmektedir. Havayolu şirketlerinin yolcu sayısını artırmak için yolcu doluluk oranını, günlük uçuş sayısını ve/veya uçak sayısını artırmaları gerekmektedir. Bu nedenle havayolu şirketlerinin yolcu sayısını artırmak için uçak satın alması beklenmektedir. Uçak satın alınabilmesi için yüksek tutarlarda özkaynaklar veya 
yabancı kaynaklara ihtiyaç duyulmaktadır. Uçak satın alımında yabancı kaynaklardan finansal kiralama yönteminin sıkça kullanıldığı daha önce belirtilmişti. Analiz sonucu da bu durumu doğrular niteliktedir. Uçak sayısı ile finansal kiralama giderleri arasında 0,457 oranında korelasyon olduğu tespit edilmiştir. Korelasyon testi sonucuna göre havayolu şirketlerinin uçak satın alırken finansal kiralama yönteminden yararlandığı analizde açıkça görülmektedir. Havayolu şirketlerinin yolcu sayıları ile satış gelirleri arasında pozitif yönlü yüksek korelasyon beklenmektedir. Modelde yer almamasına rağmen analiz sonucuna göre satış gelirleri ile yolcu sayısı arasında pozitif yönlü \%63 oranında korelasyon vardır. Analizde kullanılan değişkenlerin tanımlayıcı istatistikleri Tablo 9' da verilmiştir.

Tablo 9. Tanımlayıcı istatistikler

\begin{tabular}{lccccc}
\hline Değişkenler & $\begin{array}{c}\text { Gözlem } \\
\text { Sayısı }\end{array}$ & Minimum & Maksimum & Ortalama & Standart Sapma \\
\hline Satış Geliri & 140 & 6,3702 & 10,6608 & 9,4258 & 0,9226 \\
Faaliyet Kaldıracı & 140 & $-101,3400$ & 1769,4400 & 27,0333 & 157,2232 \\
Finansal Kiralama Giderleri & 140 & 3,4363 & 10,0247 & 7,2799 & 1,6829 \\
ROA & 140 & $-0,5600$ & 0,4000 & 0,0266 & 0,0848 \\
ROE & 140 & $-2,5800$ & 1,6900 & 0,1191 & 0,3869 \\
\hline
\end{tabular}

20 şirketin 7 y1llık verilerinden oluşan 140 gözlem değeri ile tanımlayıcı istatistiki analiz yapılmıştır. Satış gelirleri değişkeninin anlamlı sonuç vermesi için logaritması alınmıştır. Tablo 9 incelendiğinde satış gelirlerinin 6,3702 ile 10,6608 arasında değiştiği görülmektedir. Faaliyet kaldıracı değişkenin verileri çok farklılık göstermektedir. Faaliyet kaldıracının en küçük değeri -101 iken, en yüksek değeri 1769'dur. Benzer bir durumda, Lee ve Hooy (2012) tarafından yapılan bir çalışmada, Kuzey Amerika, Asya ve Avrupa kıtasındaki havayolu şirketlerinin finansal risklerine etki eden faktörler incelenmiş, Asya kıtasındaki şirketlerin faaliyet kaldıraç derecelerinin -\%2670 ile \%1851 arasında değiştiğini tespit etmiştir. Havayolu şirketlerinin satış gelirleri ile faiz ve vergi öncesi kârdaki farklılıkları faaliyet kaldıraç derecesine de yansımıştır. Finansal kiralama giderlerinde anormal bir durum söz konusu değildir. ROA ve ROE değişkenlerinin negatif değer almasının sebebi, havayolu şirketlerinin bazı dönemlerde dönem kârı olmayışıdır. Dolayısıyla şirketler söz konusu dönemlerde zarar etmişlerdir. $\mathrm{Bu}$ nedenle oranlar negatif hesaplanmıştır. ROA - \%56 ile \%40 arasında değişim göstermiştir. Dayı ve Esmer (2017a), Avrupa'da faaliyet gösteren havayolu şirketlerinin ROA değerlerinin -\%47 ile $+\% 10$ arasında değiştiğini tespit etmiştir. ROA, aktifin verimli kullanılıp kullanılmadığının tespitinde kullanılan önemli bir göstergedir. Oranın yüksek çıkması $(0,40)$ havayolu şirketlerinin varlıklarını verimli kullandıklarını göstermektedir. Ancak sabit aktifleri (duran varlıkları) çok yüksek tutarlarda olan havayolu şirketlerinin ROA değerlerinin 0,40 gibi çok yüksek değerler alması, örneklemdeki şirketlerin bazılarının toplam aktiflerinin tutarının düşük olmasıdır. ROE oranı ise -\%258 ile \%169 arasında değişmektedir. Dayı ve Esmer (2017a), Avrupa'da faaliyet gösteren havayolu şirketlerinin ROE oranlarını -\%128 ile +\%61 arasında değiştiğini tespit etmiştir. Oranın çok düşük ve yüksek olmasının sebepleri havayolu şirketlerin dönem zararlarının yüksek tutarlarda olması ve bazı havayolu şirketlerinin özkaynaklarının negatif değer almış olmasıdır. Böylece ROE hesaplanmasında, payda dönem net zararı ve payda da negatif işaretli özkaynaklar olacağından, hesaplanan değerin işareti pozitif yönlü olmaktadır.

Panel veri analizin sabit etkiler veya rassal etkiler modelinin hangisinin kullanılacağın karar vermek için Hausman Testi yapılmaktadır. Hausman testinde Prob. Değeri $<0,05$ olursa sabit etkiler yöntemi, tam tersi olursa rassal etkiler yöntemi kullanılmaktadır. Hausman testi sonuçları Tablo 10' da verilmiştir. 
Tablo 10. Hausman Testi sonucu

\begin{tabular}{lcccc}
\hline & (b) Sabit Etkiler & (B) Rassal Etkiler & b-B & S.E. \\
\hline Faaliyet Kaldırac1 & $-0,0000369$ & $-0,000033$ & $-3,98 \mathrm{e}-06$ & - \\
Finansal Kiralama Giderleri & 0,1081381 & 0,1218166 & $-0,0136785$ & 0,0075397 \\
ROA & 0,5122926 & 0,5357633 & $-0,0234707$ & - \\
ROE & $-0,0048264$ & $-0,0064615$ & 0,0016352 & - \\
Prob >chi2 $=0,6069$ & & & & \\
\hline
\end{tabular}

Hausman testi sonuçları incelendiğinde $\mathrm{P}>0,05$ 'den büyük olduğundan rassal etkiler modelinin kullanılması gerekmektedir. Hausman testi sonucunu doğrulamak ve analizin rassal etkiler mi yoksa en küçük kareler yönteminden hangisiyle yapılması gerektiğini tekrar test etmek için Breusch-Pagan Langrange Multiplier testi yapılmıştır. Breusch-Pagan Langrange Multiplier Testi sonuçları Tablo 11'de verilmiştir.

Tablo 11. Breusch-Pagan Langrange Multiplier Testi sonucu

\begin{tabular}{lcc}
\hline & \multicolumn{1}{c}{ Var } & sd = sqrt(var) \\
\hline Satı̧ Geliri & 0,8512436 & 0,9226286 \\
$\mathrm{e}$ & 0,0231702 & 0,1522175 \\
$\mathrm{u}$ & 0,6284493 & 0,7927480 \\
Prob >chibar2 =0,0000 & \\
\hline
\end{tabular}

Breusch-Pagan Langrange Multiplier testinde $\mathrm{P}>0,0000$ olduğundan Rassal Etkiler modeli ile analizin yapılması gerektiği tespit edilmiştir. Panel veri en küçük kareler yönteminde rassal etkiler modeli kullanılarak analiz yapılmış ve analiz sonuçları Tablo 12'de verilmiştir.

Tablo 12. Panel Veri Rassal Etkiler Modeli analiz sonucu

Gözlem sayıs1 $=140$

Grup sayisi $=20$

Prob $>\mathrm{F}=0,000$

\begin{tabular}{lcccc}
\hline Satış Geliri & Katsayı & Standart Hata & $\mathbf{z}$ & $\mathbf{P}>\mathbf{z}$ \\
\hline Faaliyet Kaldırac1 & 0,00047 & 9,4506000 & 4,97 & 0,000 \\
Finansal Kiralama Giderleri & 0,1191618 & 0,0281987 & 4,23 & 0,000 \\
ROA & 0,5198629 & 0,2099567 & 2,48 & 0,013 \\
ROE & $-0,0141318$ & 0,0347354 & $-0,41$ & 0,684 \\
C & 8,443641 & 0,2732856 & 30,9 & 0,000
\end{tabular}

Panel veri analiz sonuçları incelendiğinde, $\mathrm{P}$ değeri $>0,000$ olduğundan model anlamlı çıkmıştır. Satış gelirleri ile faaliyet kaldıracı arasında 0,00047 oranında pozitif yönlü bir ilişki olduğu tespit edilmiştir. Analiz sonucunda katsayının on binde dört olması faaliyet kaldıracı ile satış gelirleri arasında pozitif yönlü bir ilişki olduğunu göstermektedir. Faaliyet kaldıraç derecesinin \%-101 ile \%1769 arasında değişen bir değer alması, modelin anlamlılık düzeyini olumsuz yönde etkileyeceği düşünülse de analiz sonuçlarında değişken anlamlı çıkmıştır. Katsayının çok düşük bir değer almasının nedeninin, örneklemdeki havayolu şirketlerinin faaliyet kaldıraç derecelerinin değişim aralıklarının çok yüksek değerli olmasından kaynaklanabileceği düşünülmektedir. Faaliyet kaldıraç derecesi arttıkça havayolu şirketlerinin satış gelirlerinin artması beklenmektedir. Çalışmanın literatür kısmında belirtildiği üzere, faaliyet kaldıracı, uçuş için katlanılan yüksek tutarlı sabit giderler karşılandıktan sonraki her yolcunun marjinal gelirinin marjinal maliyetinden yüksek olduğundan, sonradan satılan her bilet şirketin satış gelirlerini yüksek oranda artırmaktadır. Dolayısıyla havayolu şirketlerinin faaliyet kaldıracından yararlanmaları tavsiye edilmektedir.

Bourjade vd. (2017) finansal kiralama giderlerinin şirketlerin optimum kâra ulaşıncaya kadar karını artırdığını tespit etmiştir. Richardson vd. (2014) finansal kiralama işleminin 
havayolu şirketlerinin finansal performansını olumlu yönde etkilediğini ifade etmiştir. Çalışmanın analizinden elde edilen bulgular literatürdeki sonuçları doğrular niteliktedir. Uygulamada, satış gelirleri ise finansal kiralama giderleri arasında pozitif yönlü bir ilişki tespit edilmiştir. Satış gelirleri ile finansal kiralama giderleri arasında \%11 oranında bir ilişki olup, satış gelirleri \%1 oranında arttığında, finansal kiralama giderlerinin \%11 oranında yükselmesi beklenmektedir. Havayolu şirketlerinin uçak satın alırken yeterli özkaynaklar ve yabancı kaynakları olmadıklarında finansal kiralama ile filolarını genişlettikleri bilinmektedir. Finansal kiralama giderleri arttığında, uçak sayısı artacağından, havayolu şirketleri daha çok yolcu taşıyacağından satış gelirlerinin artması beklenmektedir. Dolayısıyla satış gelirlerinin artması için finansal kiralama giderlerinin de artması gerekmektedir. Çalışmada finansal kiralama giderleri ile satış gelirleri arasındaki ilişkinin test edilmesinin de literatüre önemli katkı sağlaması beklenmektedir.

Faaliyet kaldıracının etkisiyle satış gelirlerinin artması beklendiğinden dolaylı olarak net kâr marjının da yükseleceği düşünülmektedir. Net kâr marjının artması, aktif toplamında bir değişiklik olmadığında aktif kârlılık oranını yükseltmektedir. Analiz sonucunda aktiflerin verimliliğini gösteren aktif kârlılık oranı ile satış gelirleri arasında pozitif yönlü bir ilişki olduğu tespit edilmiştir. Satış gelirlerindeki artış aktif kârlılığ $\% 51,9$ oranında artırmaktadır. Abbruzzo vd. (2016) tarafindan yapılan çalışmada benzer bir sonuç bulunmuş ve yolcu sayısındaki artışın, satış gelirlerini ve net kârı artırdığı ifade edilmiştir. Havayolu şirketlerinde önemli bir dezavantaj ise şirketlerin aktiflerinin yüksek tutarlarda olmasıdır. Çünkü aktif tutarı yüksek olduğundan, net kâr marjı düşük hesaplanmaktadır. Çünkü havayolu şirketlerinin maddi duran varlıklarını yüksek tutarlı uçaklardan oluşmaktadır. Bu nedenle birçok havayolu şirketi kısa vadede yolcu sayısını artırmak için faaliyet kiralaması yaptığından, kiralanan uçak için kiralama ücreti ödenmekte, uçak aktifte yer almadığı için şirketin aktif kârlılık oranı yüksek çıkmaktadır. Örneklemdeki şirketlerin aktif kârlılık oranı ortalaması \%2 civarındadır. Dolayısıyla oranın yüksek hesaplanması örneklemdeki küçük havayolu şirketlerinden kaynaklanabilmektedir. Havayolu şirketlerinin ortalama \%2 aktif kârlılık oranına sahip olmaları beklenmedik bir sonuçtur. Ancak ayrılan amortisman tutarı arttı̆̆ında, varlıkların net defter değerleri azalacağından, filosunu yenileyen şirketlerin amortisman ayırdıkları tutarlar arttıkça, aktif kârlılık oranında daha yüksek olabileceği düşünülmektedir. Özsermaye kârlılık oranı analiz sonuçları modelde anlamsız çıkmıştır. Aktif kârlılık oranından daha yüksek bir değer alması beklenmektedir. Çünkü havayolu şirketlerinin yabancı kaynakları, özkaynaklarından yüksektir. Özsermaye kârlılık oranının ortalaması \%11'dir. Örneklemdeki şirketlerin bazılarının özkaynaklarının negatif olması özsermaye kârlılık oranının düşük çıkmasına neden olmuştur. Çünkü bazı havayolu şirketlerinin özkaynakları negatif olduğundan, dönem net zararına bölündüğünde özsermaye kârlılık oranı pozitif hesaplanmaktadır. Dayı ve Esmer (2017a) faaliyet kaldıracının, özsermaye kârlılık oranları üzerinde etkisi olmadığını tespit etmiştir. Analiz sonucu bu durumu doğrular niteliktedir.

\section{Sonuç ve Öneriler}

Sivil havacılık sektörü dünyada en hızlı büyüyen hizmet ve taşımacılık sektörlerinden biri olarak ekonomiye önemli katkılar sağlamaktadır. Sektörün büyümesi için uçuş yapılan yeni hatların açılması ve günlük sefer sayısının artırılması gerekmektedir. Böylece daha fazla yolcu taşınabilecek ve şirketlerin taşıdıkları yolcu sayısı da artacaktır. Havayolu şirketleri sefer sayısını ve uçuş noktalarını genişletmek için filodaki uçak sayısını yükseltmesi gerekmektedir. Yeni uçakların satın alınması yüksek duran varlık yatırımını gerektirmektedir. Bu durumda şirketler yeni finansman kaynakları arayışına gireceklerdir. Yabancı kaynakların artması şirketlerin finansal riskinin de artmasına neden olabilecektir. Havayolu şirketlerinde finansal sürdürülebilirlik için optimum sermaye yapısı ile duran varlıkların finanse edilmesi oldukça önemlidir. Çünkü sivil havacılık sektörü yoğun sermaye gerektiren bir sektör olup değişken giderler düşük, sabit giderler yüksektir. Uçakların satın alınmasından sonra uçağın sefer başına toplam yolcu sayısının küçük bir kısmından elde edilen gelirler (uçakların yolcu sayısının 
yüksek olmasından dolayı) ile sabit giderler karşılandığından, uçaktaki diğer yolcuların sadece değişken giderleri olacağından, havayolu şirketlerinin faaliyet kaldıracının etkisiyle satış gelirlerinin artması beklenmektedir. Böylece uçaktaki yolcunun marjinal geliri marjinal maliyetinden daha yüksek olacağından havayolu şirketlerinin faaliyet kaldıraç oranı yükselmektedir. Faaliyet kaldıraç derecesi ile satış gelirleri arasında pozitif yönde bir korelasyon vardır. Uçaktaki yolcu sayısı arttıkça, kaldıraç etkisiyle daha fazla satış geliri elde edilmektedir. Doluluk oranının artması şirketlerin performansını da olumlu yönde etkilemiştir.

Satış gelirleri faaliyet kaldıracı arasında pozitif yönde bir ilişkinin olması beklenmektedir. Analiz sonuçları da bu durumu doğrulamaktadır. Çünkü yüksek düzeyde kaldıraç oranı şirketlerin daha fazla kâr etmesini sağlamaktadır. Ancak bunun gerçekleşmesi kısa sürede mümkün olmayabilir. Çünkü uçak üreten şirketlerin sayısının az oluşu ve uçak yapımının uzun süre alması, uçak arzını olumsuz yönde etkilemektedir. Uçak yapımı uzun yıllar almaktadır. Şirketler uçak satın almak için sipariş vermekte ve birkaç yıl içerisinde teslimat yapılmaktadır. Finansal kiralama, birçok havayolu şirketinin sıkça kullandığı bir yöntemdir. Finansal kiralama giderleri ile satış gelirleri arasında pozitif yönlü bir ilişki vardır. Havayolu şirketleri satın alma veya finansal kiralama yöntemlerinde uçağın hemen teslim edilmemesinden dolayı faaliyet kiralaması yöntemi kullanılmakta, uçak kabin ekibi ve pilotlarıyla birlikte şirketlerden belirli bir süre için kiralanmaktadır. Böylece kısa sürede koltuk arzı artmakta ve daha fazla yolcu taşınabilmektedir. Havayolu şirketlerinin en önemli maliyetleri yakıt ve personel maliyetleridir. Uçağın sabit giderleri karşılandıktan sonra, taşınan her yolcunun değişken maliyetleri düşük olduğundan, bilet fiyatının büyük bir kısmı doğrudan kâra dönüşebilmektedir. Satış gelirleri ile aktif kârlılık oranı arasında pozitif yönde bir ilişki vardır. Özsermaye kârlılık oranı negatif özkaynaklara sahip şirketlerde anlamlı sonuç vermesi beklenmediğinden, oranın anlamsız çıkması doğal bir sonuç olarak görülmektedir.

Sivil havacılık sektöründeki havayolu şirketlerinin sayısının artırılması, daha fazla ve daha farklı yerlere sefer düzenlenmesi, yakıt maliyetlerinin dünya genelinde düşürülmesi ve sivil havacılık için vergi teşviki sağlanması ve uçak üreten şirketlerin sayısının artırılması önerilmektedir. Dünyada nüfusun artmasından dolayı sivil havacılık sektörünün daha da büyümesi beklenmektedir. Sivil havacılık sektöründe maliyet-hacim-kâr analizi yapılabilir. Havayolu şirketlerinde verimlilik artışı için şirketlerin finansal ve operasyonel verilerinden yararlanılarak etkinlik ve verimlilik analizlerinin yapılmasının literatüre katkı sağlaması beklenmektedir.

\section{Kaynakça}

Abbruzzoa, A., Fasone, V. ve Scuderi, R. (2016). Operational and financial performance of Italian airport companies: A dynamic graphical model, Transport Policy, 52: 231-237.

Akgüç, Ö. (1998). Finansal Yönetim, İstanbul: Muhasebe Enstitüsü Eğitim ve Araştırma Vakfı .

Alaghi, K. (2012). Operating leverage and systematic risk, African Journal of Business Management, 6(3): 1095-1099.

American Airlines. (2017). American Airlines Annual Reports, https://americanairlines.gcsweb.com/financial-results/financial-aal (Erişim Tarihi: 08.01.2017).

Air China (2017). Air China Annual Reports, http://www.airchina.com.cn/en /investor_relations/index.shtml, (Erişim Tarihi: 08.01.2017).

Air Asia (2017). Air Asia Annual Reports, https://ir.airasia.com/ar.html, (Erişim Tarihi: 08.01.2017).

Air New Zeland (2017). Air Nez Zealand Annual Reports", https://www.airnewzealand.co.nz/ latest-annual-and-interim-results, (Erişim Tarihi: 08.01.2017). 
Bayraktutan, Y., ve Demirtaş, I. (2011). Gelişmekte Olan Ülkelerde Cari Açığın Belirleyicileri: Panel Veri Analizi, Kocaeli Üniversitesi Sosyal Bilimler Enstitüsü Dergisi, 22: 1-28.

Bourjade, S., Huc, R. ve Muller-Vibes, C. (2017). Leasing and profitability: Empirical evidence from the airline industry, Transportation Research Part A, 97:30-46.

Brigham, E. F. ve Houston, J. F. (2014). Fundamentals of Financial Management (Finansal Yönetimin Temelleri, Çev. Edi: Nevzat Aypek), Ankara: Nobel Yayıncılık.

China Eastern Airlines (2017). China Eastern Airlines Annual Repors, http://www.irasia.com/listco/hk/chinaeast/annual/index.htm (Erişim Tarihi: 08.01.2017).

China Southern Airlines. (2017). China Southern Airlines Annual Report, http://www.csair.com/en/about/investor/ (Erişim Tarihi: 08.01.2017).

Day1, F. ve Esmer, Y. (2017a). Measuring Financial Performance of Airline Passenger Transport Company in European. 33rd International Academic Conference, (s.26-37). Vienna.

Day1, F. ve Esmer, Y. (2017b). Sivil Havacılık Yönetiminde Finansal Kiralama İşlemlerinin Karlılık Üzerine Etkisi: Avrupa Havayolu Şirketleri Üzerine Bir Uygulama, Akademik Bakış Uluslararası Hakemli Sosyal Bilimler E- Dergisi, 64: 69-78.

Day1, F. ve Ulusoy, T. (2018). Evaluating Financial Performance with Minimum Spanning Tree Approach: An Application Airlines Companies, Turkish Studies Economic, Finance and Politics, 13(30): 89-103.

Delta Airlines (2017). Delta Airlines Annual Reports, https://ir.delta.com/, (Erişim Tarihi: 08.01.2017).

Dran, J. and. John, J. (2001). A Different Perspective on Operating Leverage, Journal of Economics and Finance, 87-94.

Easyjet. (2017). Easyjet Annual Reports, http://corporate.easyjet.com/investors, (Erişim Tarihi: 08.01.2017).

Emirates. (2017). Emirates Annual Reports, https://www.emirates.com/english/aboutus/business-model/financial-transparency.aspx, (Erişim Tarihi: 08.01.2017).

Ercan, M. K. ve Ban, Ü. (2012). Değere Dayalı İsletme Finansı Finansal Yönetim, Ankara: Gazi Kitabevi.

Erickson, S. M. ve Trevino, R. (1994). A Pecking Order Approach to Leasing: The Airline Industry Case, Journal of Financial And Strategic Decisions, 7(3): 71-81.

Exchangerate. (2018). Foreign Money Exchange Rate, https://www.exchangerates.org.uk/, (Erişim Tarihi: 01.12.2018).

Fitó, M. Á., Moya, S. ve Orgaz, N. (2014). Considering the effects of operating lease capitalization on key financial ratios, Spanish Journal of Finance and Accounting, 42(159): 341-369.

France-KLM, A. (2017). Air France-KLM Annual Report, https://www.airfranceklm.com/en/ finance/publications/results, (Erişim Tarihi: 08.01.2017).

Gahlon, J. M. ve Gentry, J. A. (1982). On the Relationship between Systematic Risk and the Degrees of Operating and Financial Leverage, Financial Management, 11(2):15-23.

Gavazza, A. (2010). Asset liquidity and financial contracts: evidence from aircraft leases, Journal of Financial Economics, 95: 62-84. 
Gritta, R. D., Lippman, E. ve Chow, G. (1994). The impact of the capitalization of leases on airline financial analysis: An issue revisited, Logistics and Transportation Review, 30(2): 189-202.

Group, A. B. (2017). Air Berlin Group Annual Reports, http://ir.airberlin.com/en/ir, (Erişim Tarihi: 08.01.2017).

Holdings, A. (2017). ANA Holdings Annual Report, https://www.ana.co.jp/group/ en/investors/irdata/supplement/, (Erişim Tarihi: 08.01.2017).

Hsiao, C. (2014). Analysis of Panel Data, USA: Cambridge University Press.

Huffman, L. (1983). Operating Leverage, Financial Leverage and Equity Risk, Journal of Banking and Finance, 7: 197-212.

IATA. (2017). IATA World Air Transport Statistics. London: IATA.

Korkmaz, T., Yıldız, B. ve Gökbulut, R. İ. (2010). FVFM'nin İMKB ulusal 100 endeksindeki geçerliliğinin panel veri analizi ile test edilmesi, İstanbul Üniversitesi İşletme Fakültesi Dergisi, 39(1): 95-105.

Lee, C.-H. ve Hooy, C.-W. (2012). Determinants of systematic financial risk exposures of airlines in North America, Europe and Asia, Journal of Air Transport Management, 24: 3135 .

Lee, J.-S. ve Jang, S. (2007). The systematic-risk determinants of the US airline industry, Tourism Management, 28: 434-442.

Lev, B. (1974). On the Association Between Operating Leverage and Risk, The Journal of Financial and Quantitative Analysis, 9(4):627-641.

Lufthansa. (2017). Lufthansa Annual Reports, https://investor-relations.lufthansagroup.com/ en/publications/financial-reports.html, (Erişim Tarihi: 08.01.2017).

Morrell, P. S. (2007). Airline Finance. USA: Ashgate Publishing, Ltd.

Nicolau, J. L. ve Santa-María, M. J. (2012). Effect of innovation on airlines' operating leverage: A Spanish case study, Journal of Air Transport Management, 25: 44-46.

Novy-Marx, R. (2011). Operating Leverage, Review of Finance, 15(1), 103- 34.

O'Brien, T. J. ve Vanderheiden, P. A. (1987). Empirical Measurement of Operating Leverage for Growing Firms, Financial Management, 16(2):45-53.

Oum, T. H., Zhang, A. ve Zhang, Y. (2000). Optimal demand for operating lease of aircraft, Transportation Research B, 34: 17-29.

Pasific, C. (2017). Cathay Pasific Annual Reports, https://www.cathaypacific.com/ cx/en_ID/about-us/investor-relations/interim-annual-reports.html, (Erişim Tarihi: 08.01.2017).

Percival, J. R. (1974). Operating Leverage and Risk, Journal of Business Research, 2(2): 223227.

Prezas, A. P. (1987). Effects of Debt on the Degrees of Operating and Financial Leverage, Financial Management, 16(2): 39-44.

Richardson, C., Budd, L. ve Pitfield, D. (2014). The impact of airline lease agreements on the financial performance of US hub airports, Journal of Air Transport Management, 40, 1-15.

Ryanair. (2017). Ryanair Annual Reports, https://investor.ryanair.com/, Erişim Tarihi: 08.01.2017). 
Qantas Airways (2017). Qantas Airways Annual Reports, https://investor.qantas.com /investors/?page=annual-reports, (Erişim Tarihi: 08.01.2017).

Schönenberger, F. (2014). Operating Leverage-Is Cost Structure Rigidity A Characteristic of Risk? The Impact of Cost Structure Rigidity on Returns under Consideration of BM Ratio and Size. St.Gallen: Universtiy of Gallen School of Mangement, Economics, Law, Social Sciences and International Affairs, Doctor of Philosophy in Management, St. Gallen.

Shrieves, R. E. (1981). Uncertainty, the Theory of Production, and Optimal Operating Leverage, Southern Economic Journal, 47(3): 690-702.

Singapore Airlines (2017). Singapore Airlines Annual Repors, https://www.singaporeair.com/ en_UK/us/about-us/information-for-investors/, (Erişim Tarihi: 08.01.2017).

Southwest Airlines (2017). Southwest Airlines Annual Reports, http://www.southwestairlinesinvestorrelations.com/, (Erişim Tarihi: 08.01.2017).

Stowe, J. D. ve Ingene, C. A. (1984). Microeconomic influences on operating leverage, Journal of Economics and Business, 36(2):233-241.

TCMB. (2018). Türkiye Cumhuriyet Merkez Bankası Çapraz Kur Verileri, https://www.tcmb.gov.tr/kurlar/kurlar_tr.html, (Erişim Tarihi: 01.12.2018).

THY. (2017). Türk Hava Yollarl Faaliyet Raporu, https://investor.turkishairlines.com/tr/maliveriler/yillik-raporlar/1/2016, (Erişim Tarihi: 08.01.2017).

United Airlines (2017). United Airlines Annual Reports, http://ir.united.com/, (Erişim Tarihi: 08.01.2017). 